\title{
The Unruly Character of Politics
}

\author{
Owen M. Fiss ${ }^{*}$
}

Every age has its issue and ours may be abortion. It has posed many challenges to the Supreme Court, above all that of reexamining the long discredited doctrine of substantive due process. The 1973 ruling in favor of the individual woman's right to choose to have an abortion sharply divided the Court and over the next two decades the Court has had to revisit the issue to see whether the initial ruling should be affirmed, as indeed it has been. ${ }^{1}$

Beyond that, the Court has had to find a place within the constitutional order for the losers: To what extent shall those opposed to abortion be allowed to air their views and keep the controversy alive? Because the pro-life forces have not been content to advance their cause only through the ballot box or the courts, but have most decidedly taken to the streets, specifically to picket abortion clinics and the doctors who work in them, the abortion controversy has also forced the Supreme Court to probe the limits of the First Amendment and its guarantee of free speech. This is my subject.

\section{I.}

Some commentators have cast the function of the First Amendment in individualistic terms and portray it as a protection of each person's right to selfexpression. To these theorists, speaking is just another individual activity, comparable to hiking or working, and like those activities should be free from state interference unless the state can come forward with a pretty good reason for its action. This theory does not, however, fully explain the special commitment the Constitution has toward the protection of speech. A better reason is needed for

* Sterling Professor of law, Yale University. The idea for this essay first took shape in my free speech course at Yale in the spring of 1996. I am grateful to the students in that course for helping me to understand the issues more fully. The following year, one of those students, Benjamin Sachs, worked with me on these issues in an independent research project and produced an important paper on the subject entitled, "Residential Picketing and the First Amendment." At moments, I do not know where his ideas end and mine begin. Participating in the faculty lecture series at the McGeorge Law School in January 1997, provided a further occasion to refine my thoughts, and I wish to thank the students and faculty of McGeorge, especially my good friend Brian $\mathrm{K}$. Landsberg, for their warm hospitality and spirited discussion. I also wish to acknowledge the contributions to this essay of Bruce A. Ackerman, Patricia L. Cheng, Paul W. Kahn, Tamarra D. Matthews, and Gregory S. Silbert. Their comments and criticism helped me enormously.

1. See Roe v. Wade, 410 U.S. 113 (1973); Planned Parenthood v. Casey, 505 U.S. 833 (1992). 
protecting speech and in search of that reason the prevailing theory of the Amendment ties the right of free speech to society's interest in democracy. ${ }^{2}$

Within the terms of individualistic theory, it is hard to understand why the interests of speakers or protestors should take priority over the interests of those hurt or offended by the speech, or simply inconvenienced by it. There would be a conflict of individual interests and no basis for preferring one over the other. The Constitution is not, however, neutral in this conflict. It tilts the scales in favor of the speaker, and the most plausible explanation for this tilt arises from the contribution speech makes to democracy. According to this theory, which so dominates the field today, what the First Amendment seeks to further is not self-expression, but collective self-determination.

The democratic theory of the First Amendment can be traced to the work of Alexander Meiklejohn and Harry Kalven, who, in turn, often made recourse to the metaphor of a town meeting to elaborate upon the role of speech in the process of collective self-determination. ${ }^{3}$ In this metaphor, society is viewed as a gigantic assembly in which all the citizens are gathered. The citizens need to make a decision on some pressing issue of the day, but before doing so they must hear all the conflicting viewpoints. Speaker after speaker rises to identify the options before the gathering and provide the information needed to assess those options. Those participating in the town meeting will listen, argue, and then, finally, vote. The vote is the act of collective self-determination and the speeches that occur before that vote enable citizens to understand themselves, identify their needs, and discover how those needs might be satisfied. In the context of a town meeting, speech is a form of enlightenment.

Although some forms of protest activity comport with the understanding of the function of speech projected by the metaphor of the town meeting, this is not true of the most salient form of protest activity of the anti-abortion movement these days-picketing in front of abortion clinics or the homes of doctors who perform abortions. Such picketing makes claim to protection of the First Amendment and invokes the democratic theory of Meikeljohn and Kalven to support that claim, but on reflection seems only tenuously connected to enlightenment.

True, these picketers usually carry signs, "Abortion kills," "Doctor Jones is a Murderer," or "Jesus Saves." Sometimes the protestors convey the same message through shouting or singing and to the extent that they do, they may be seen as the equivalent of the speakers in a town meeting. They too are engaged in the process of enlightenment in so far as they make reasons and arguments publicly available, and

2. See, e.g., STEVEn H. SHIFrR, ThE FIRST AMENDMENT, DEMOCRACY, AND ROMANCE (1990); Lee C. Bollinger, Free Speech and Intellectual Values, 92 YALE L.J. 438 (1983); Robert H. Bork, Neutral Principles and Some First Amendment Problems, 47 IND L.J. 1 (1971); Paul G. Stern, Note, A Pluralistic Reading of the First Amendment and Its Relation to Public Discourse, 99 YALE L.J. 925 (1990).

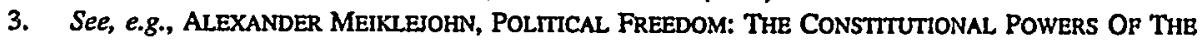
PEOPLE 24 (1960); Hanry Kalven, Jr., The Concept of the Public Forum: Cox v. Louisiana, 1965 SUP. CT. REv. 1. 
apply them to an issue of great public significance. But this overlooks one crucial feature of picketing, namely its locational specificity-it takes place in front of a particular physical structure, say, an abortion clinic or the doctor's house.

Picketing has a long and noble history in American politics, used not just by prolifers, but also by organized labor, the anti-Vietnam war movement, and perhaps most heroically by civil rights activists. ${ }^{4}$ In many of these cases, say labor, the locational specificity of picketing can be justified in enlightenment terms. The relevant public the union wishes to reach are the customers who are about to use the store, and the most sensible way of reaching those persons and informing them of the labor dispute is by marching or standing in front of the store. In the case of abortion picketing, however, there is no analogous rationale for the targeted quality of the protest activity.

Picketing in front of the doctor's house does not tell the doctor anything he does not already know, whether that he performs abortions or that some citizens believe such activity to be immoral. The doctor's neighbors may not know that he performs abortions, but to convey that message the picketers need not stand in front of the doctor's house. Indeed, that site does not seem an especially compelling way of informing the public or the doctor's neighbors. If their purpose is to enlighten the neighbors or the public in general, the protestors may walk through the neighborhood, send letters to the neighbors, stand on the town green, or distribute flyers outside the local shopping center.

Similarly, no new information is conveyed by picketing an abortion clinic. The relevant targets of this activity are the persons who work in the clinic and those who are about to use the services offered, but these persons know everything that the protestors seek to tell them. The facility holds itself out as an abortion clinic. Every one who enters it, and thus encounters the picketers on the way in, already knows whatever the picketer is likely to say. As with the residential picketers, the protestors in front of the abortion clinic may have their eyes on the broader public, for example, persons who casually drive by or who might watch a news broadcast of the picketing on television later that night. But once again, that purpose does not require that the picketers patrol in front of the clinic. Many alternative sites are available for informing the public of their cause.

Maybe the persons about to use the clinic or the doctors who perform abortions need a reminder about the moral consequences of their action. That is, however, hardly the kind of enlightenment contemplated in the town meeting. A speaker who stubbornly and constantly reiterates a well-known position stands on different footing than a speaker who aims to impart new information or to elaborate on a point through reasoned arguments.

The locational specificity of abortion picketing is in fact crucial to the protesters. To understand why, however, we need to change the terms of reference and under-

4. See generally HARRY KalVEN, JR., THE NEGRO AND THE FIRST AMENDMENT (1966). 
stand that the purpose of such picketing is not enlightenment but confrontation. Abortion picketers are confronting the doctors, nurses, and pregnant women on the moral consequences of their actions in an effort to get them to desist from those actions. In biblical terms, they see themselves as bearing witness to a grave misdeed.

A moral confrontation, as exemplified by abortion picketing, consists of four elements. First, there must be a declaration of opposition and an indication of the grounds of opposition. This is the function of the signs the picketers carry and, to a certain extent, the songs that they sing.

Second, confrontation requires a sacrifice or inconvenience on the part of the protestors. In fact, the word "witness," as it appears in the Bible, is a translation of the Greek word "martys," which is etymologically connected to "martyr." The sacrifice implied in witnessing, or a moral confrontation, indicates the moral seriousness of the objection being voiced and thus adds weight to that objection. Spending time on a picket line in front of a doctor's house or a clinic is indeed a sacrifice, though, of course, the measure of the sacrifice increases as the fair weather turns to rain, and as the patrolling takes place during the workday. Among its many functions, the singing on a picket line, like the hymns in a religious service, binds people together and strengthens their resolve to take a stand and suffer the necessary sacrifices.

Third, a moral confrontation requires a public encounter between the objector and the wrongdoer. The need for such an encounter explains the locational specificity of the picketing - why it must be in front of the doctor's house or the clinic and not on the town green or elsewhere in the neighborhood. The physical proximity of objector and wrongdoer signifies that both are members of the same community and that, by virtue of this fact, the objector has the right to make claims upon the alleged wrongdoer.

Fourth, the purpose of this encounter is to change behavior, and it seeks to achieve this purpose not by the persuasive force of an argument but by the demonstration of moral seriousness. The changes sought by a parade or mass demonstration are general in nature-a change in the law, for example. In contrast, the behavioral changes contemplated in targeted picketing in the abortion context tend to be more individualized. Those on the picket line hope to save fetus after fetus by confronting those performing abortions or those about to have them.

Confrontation has an important role to play in democratic politics, and thus can rightly make claim to protection under the First Amendment. That is why picketing is speech. Of course, as a matter of ordinary discourse, picketing, whether its purpose be enlightenment or confrontation, is not considered speech, but that is not the appropriate test. As in all legal interpretation, to demarcate the bounds of the First Amendment we proceed by identifying the underlying purpose of that constitutional provision and then give meaning to the critical phrases in light of that purpose. ${ }^{5}$

5. See generally Bruce A. ACkerman, Private Property And The Constitution (1977); Kalven, supra note 4. 
Constitutional interpretation is a matter of functional analysis, not ordinary language, and from that vantage point, picketing should be considered speech or, more specifically, as falling within the ambit of "the freedom of speech" because of its contribution to the democratic practice of self-governance. This is true whether the purpose of picketing be enlightenment or confrontation.

Admittedly, confrontation has no place in the town meeting, but that now strikes me as a limitation of the metaphor. ${ }^{6}$ Reference to the town meeting seems unfortunate in so far as it ties speech to the vote and thus reduces self-determination to the electoral process. Periodic elections are indeed crucial to democracy, for they put the ultimate power of governance in the hands of citizens, yet we should not make, and have not made, elections the full measure of democracy. Supplements or correctives are sometimes needed and confrontational protests, like picketing, might usefully be seen as an electoral supplement.

The need for such a supplement was abundantly clear in the civil rights context, and that is why confrontational politics was so privileged there. In many instances, blacks were disenfranchised and thus systematically excluded from the electoral process. Even when that was not the case, the need for an electoral supplement arose from their status as "a discrete and insular minority"-few in number and victims of traditions of prejudice that disabled them from forming or participating in the coalitions that are the mainstay of electoral politics. ${ }^{7}$ Those who engage in abortion protests are not disenfranchised nor are they a discrete and insular minority-for a good part of our history they have been the victors in electoral politics. Yet they too can point to shortcomings of the electoral process and thus make a strong case for the need for confrontational politics.

One of their needs derives from the constitutionalization of the abortion debate that has occurred over the last 25 years, first in Roe v. Wade and then again in Casey. Those decisions increased the electoral burdens that those opposed to abortion must surmount. No simple majority suffices for them. In order to achieve their purposes, they must garner the support needed for a constitutional amendment or some decisive shift in Court personnel.

Another need for an electoral supplement-shared by all protestors, regardless of their cause-derives from the well-known difficulty of registering intensities through voting. Although the importance people attach to their position varies greatly from person to person and although the depth of their feeling can be expressed in their speeches, in what they say as well as how they say it, all these differences are

6. For a different criticism of the town meeting, see Robert C. Post, Meiklejohn's Mistake: Individual Autonomy and the Reform of Public Discourse, 64 U. COLO. L. REV. 1109 (1993), reprinted in ROBERT C. POST, CONSTIUUTIONAL DOMAINS: DEMOCRACY, COMMUNTTY, MANAGEMENT 268 (1995). For my response to Post, see OWEN M. FISS, The Right Kind of Neutrality, in LIBERALISM DIVIDED 109 (1996). For a more extensive analysis and critique of Post's position, see Morris Lipson, Note, Autonomy and Democracy, 104 YALE L.J. 2249 (1995).

7. United States v. Carolene Products Co., 304 U.S. 144, 152 n.4 (1938). For a consideration of the role of minorities in the democratic process, see JOHN HART ELY, DEMOCRACY AND DISTRUST: A THEORY OF JUDICLAL ReviEw (1980); Bruce A. Ackerman, Beyond Carolene Products, 98 HARV. L. Rev. 713 (1985). 
washed out when it comes to voting. Each person in the town meeting has only one vote. The "one person, one vote" rule may be democracy's way of affirming the moral equality of citizens on an abstract and symbolic level, but this does not deny the relevance or importance of registering intensities in collective-will formation. Confrontational politics is a way of giving expression to those intensities.

Protests also have an agenda-setting function. Politicians have an incentive to avoid taking positions on divisive issues, as any such position will alienate some portion of the electorate. But a democracy is not well served if its officials systematically skirt issues of overriding importance to private citizens. Protests are an important means of spotlighting those issues, and thus setting the agenda on which future elections will be won or lost.

Moreover, protests advance an important democratic function insofar as they are issue-specific. A vote for a particular candidate endorses a bundle of economic and social policies, and will invariably entail some measure of compromise. Thus, a pro-choice majority may elect a pro-life candidate if, for example, that candidate espouses popular fiscal policies. As most matters of public significance are not determined by referendum, citizens rarely have an opportunity to register their views on specific issues. Protesting focuses criticism on the activity that inspires it, rather than filtering criticism through a political candidate who will generally be associated with a broad range of policies and positions.

Elections occur at regular intervals-2 years, 4 years, and sometimes even 6 years. Protests give the citizens the capacity to address issues of public importance during the interim, to respond to a new change or a shift in public policy, or as a way of keeping controversy alive between elections.

Finally, protests emphasize that certain social phenomena are objectionable for reasons of morality, as opposed to reasons of policy, and allow the individual to make clear the grounds of objection. Opposition to a city sponsored abortion clinic may be based on many grounds-fiscal conservatism, a desire to preserve the residential character of a neighborhood, the fear of an increase in traffic, or the moral character of the action occurring there. Voting in an election, or even a referendum, does not permit the citizen to give the ground of objection or to reveal its special character and the kind of response that will suffice-arguments from principle deserve a principled answer.

II.

Emphasizing the confrontational rather than the informational element of picketing requires us to reexamine the nature of democratic politics, to avoid the reduction of democracy to elections and to see the need for what I have called electoral supplements. This conception of picketing also places the need for state regulation in proper perspective. Even in the town meeting, where speech is informational, the state has an important role to play; the state must act as a parlia- 
mentarian, making certain that all voices are heard. ${ }^{8}$ However, the need for state intervention is significantly more urgent in a moral confrontation, for the danger is ever present that the public encounter that lies at the core of that activity will get out of hand. Objectors, driven by moral or even religious imperatives and prepared to make sacrifices for the good of the cause, are likely to press and press until their aims are achieved. The state must set the bounds on the confrontation.

The state commonly seeks to perform this function through the issuance of injunctions. The great attraction of the injunction as a regulatory instrument arises from its context specificity. Because an injunction is issued in a particular case, it can take into account the particular circumstances of the situation at hand and thus regulate with a great deal of precision. ${ }^{9}$ No more speech need be curbed than necessary. The injunction was commonly used to regulate picketing in the labor context, and again during the civil rights era. But in the early 1970s it became ensnared in a First Amendment doctrine-the rule against prior restraints-that threatened its availability in the abortion context.

Standard First Amendment doctrine disfavors any regulation of speech. This applies to criminal statutes as well as injunctions. In 1971, in the Pentagon Papers case, however, the Supreme Court placed a special disability on injunctions, thereby making them even more disfavored than criminal statutes. ${ }^{10}$ Classifying injunctions as prior restraints, the Court ruled that, save in the most exceptional circumstances, for example, to prevent a publication that would disclose troop movements, judges should never issue injunctions against speech. Of course, the doctrine that treated injunctions as prior restraints pre-dated the Pentagon Papers case. In fact, its roots can be traced all the way back to Near v. Minnesota in the 1930s. ${ }^{11}$ But the Pentagon Papers case gave that doctrine a very special authority and prominence and thus created in the modern period a most formidable barrier against the issuance of injunctions regulating protest activities.

In my view, this turn in the law was unfortunate, for it ignores the structural similarity between criminal statutes and injunctions-both try to prevent future action by threatening punishment. In a sense, both are prior restraints, and there is no reason to place special disabilities on injunctions or to make them more disfavored than criminal statutes. Injunctions are more specific than statutes, but the ability to fine-tune regulation allows the state to suppress unacceptable conduct without constraining activities worthy of First Amendment protection.

8. For an elaboration of this claim, see OWEN M. Fiss, The IRONY OF FreE SPEECH (1996).

9. Thus, injunctions have a certain advantage over statutes, which necessarily deal in generalities. See, e.g., Freedom of Access to Clinic Entrances, 18 U.S.C.S. $\S 248$ (Law. Co-op Supp. 1997) (prohibiting injury of, intimidation of, or interference with, persons entering a reproductive health facility). 18 U.S.C.S. \$ 248(d)(1) stipulates that the statute shall not be construed to prohibit any activity protected by the First Amendment, but cannot, of course, specify what conduct is permissible in any particular case.

10. New York Times Co. v. United States, 403 U.S. 713 (1971).

11. 283 U.S. 697 (1931). 
Individuals charged with violating a criminal statute can claim in defense that the statute violates the First Amendment. In contrast, individuals charged with violating an injunction may under certain circumstances be barred from raising any First Amendment objections to the order. ${ }^{12}$ But this difference between criminal statutes and injunctions is entirely of the Supreme Court's creation. It would thus be the most flagrant of bootstrap arguments if this difference was used to justify the extra burden on injunctions. It would be much more sensible to lift what is referred to as the "collateral bar rule" and allow the First Amendment defense to be asserted in the criminal contempt proceeding than to bar their use altogether in managing confrontational politics.

For these reasons, during the 1970s and 1980s a number of commentators, including myself, maintained that the prior restraint doctrine should not be applied to injunctions. ${ }^{13}$ Injunctions should be strictly scrutinized, but no more or less so than criminal statutes. Yet the Court was of a different mind. In fact, following the Pentagon Papers decision the prior restraint doctrine became a favorite of the Burger Court and was invoked with greater and greater frequency. In 1994, however, in the context of abortion picketing, the Court began to disentangle the use of the injunction from the prior restraint doctrine and took the law of injunctions in a different direction.

In the case in question, Madsen v. Women's Health Center, Inc. ${ }^{14}$ Chief Justice Rehnquist, writing for the Court, upheld a state court injunction that created a buffer zone between pro-life picketers and the entrance of the clinic. A small road ran in front of the clinic, and the picketers were ordered to stand on the other side of that road- 36 feet from the entrance of the clinic, to be precise. The picketers objected to this injunction on the ground that it was a prior restraint. In a footnote, of all places, the Court brushed the objection aside and distinguished the injunction sought in the Pentagon Papers case on two grounds. The Court stressed, first, that the Madsen injunction, unlike the one sought in Pentagon Papers, did not prohibit all speech, but only geographically limited it. Second, the Court pointed out that the Madsen injunction was not based on the content of the speech.

The first ground of distinction seems a little strained. The Pentagon Papers case, and one of its immediate antecedents, ${ }^{15}$ treated even interlocutory injunctions as prior restraints. Such injunctions merely seek to delay or postpone a speech for a limited period of time ( 10 days or for the duration of a trial), and thus are limited in their reach-not geographically, but temporally. Still, the practical effect of the Court's

12. See Walker v. City of Birmingham, 388 U.S. 307 (1967). For a discussion of Walker, see David Luban, Difference Made Legal: The Court and Dr. King, 87 MICH. L. REv. 2152 (1989).

13. See, e.g., OWEN M. FISS, Free Speech and the Prior Restraint Doctrine, in LIBERALISM DIVIDED 121 (1996); OWEN M. FISS, The CIVIL RIGHTS INJUNCtION (1978); Stephen R. Bamett, The Puzzle of Prior Restraint, 29 StaN. L. REv. 539 (1977); John Calvin Jeffries, Rethinking Prior Restraint, 92 YALE L.J. 409 (1983).

14. 512 U.S. 753 (1994).

15. Carroll v. President of Princess Anne, 393 U.S. 175 (1968); see also Organization for a Better Austin v. Keefe, 402 U.S. 415 (1971) (treating a temporary injunction as a prior restraint). 
first ground of distinction-sound or not-was to take the injunction out from the cloud created by Pentagon Papers and enable it to be used-without a presumption of invalidity-to keep the lid on abortion picketing. Such injunctions do not ban speech altogether, but only define the terms on which it will proceed.

The Court's second ground of distinction had a similar effect. There, the Court tied the prior restraint doctrine to another doctrine that had come into prominence in the 1970 s and 1980 s - the rule against content regulation-and that tie effectively rendered the prior restraint objection redundant. Like the prior restraint doctrine, the rule against content regulation creates a strong presumption of invalidity, but is not in any way keyed or limited to injunctions. It does not rest on any alleged special feature of the injunction, say, its forward-looking quality. Rather, it seeks to give expression to the democratic purpose underlying the First Amendment by barring the state from manipulating the public's decision by favoring one side of the debate over another. As a result, the rule against content regulation disfavors speech regulations of any type, provided, of course, one side of the debate is singled out for especially favored or disfavored treatment.

In his dissent in Madsen, Justice Scalia invoked the rule against content regulation and, with an intemperance that served no one well, insisted that the injunction should be subject to the near-fatal scrutiny called for by that rule. ${ }^{16}$ Chief Justice Rehnquist, no less committed to overturning Roe, calmly but firmly disagreed. Paralleling his treatment of the prior restraint doctrine, the Chief Justice refused to burden injunctions regulating picketing with the presumption of invalidity that comes from the rule against content regulation. Every injunction, he acknowledged, is context specific, but it is not context specificity that makes an injunction transgress the rule against content regulation. That rule would be violated only if a disability were placed on one group of protestors-the pro-lifers-that would not be placed on others, for example, those in favor of choice, or those engaged in labor or civil rights struggles against the clinic. The judge issuing the injunction did not address or provide those hypothetical situations, nor should he have, but the mere fact that the injunction is addressed to one particular contestant does not necessarily mean that they were singled out for especially disfavored treatment.

Admittedly, the context specificity of the injunction presents, as Scalia warned, the danger of abuse. Confronting a specific protest the judge may give vent to his feelings about the merits of the protest and structure the order issued in such a way as to make it harsher on the pro-lifers than it would be if he were confronted with picketing by pro-choice or civil rights activists. The dispute in all its particularity is before the judge and he may be swept up in it. But to treat injunctions as presumptively invalid for that reason seems to make too much of the risk of abuse. It

16. Justice Scalia refers to a videotape of the picketing which was made by employees of, or volunteers at, the abortion clinic. According to Justice Scalia, "Anyone seriously interested in what this case was about must view the tape." 512 U.S. at 786. In an effort to comply, I attempted to obtain the tape, only to learn that it is not on record with the Court. I was eventually able to procure a copy, and it is now on file at the library of the Yale Law School. 
overlooks a judge's capacity for impartiality. It also slights the genuine advantages to First Amendments values that come from allowing the government to regulate through injunctions as opposed to criminal statutes. As the Norris-LaGuardia Act teaches, in the labor context there may be special reasons for disfavoring injunctions; the privileged economic status of judges may lead them to identify with the employer. ${ }^{17}$ But no such reason for systematic distrust exists in the abortion context.

The Madsen Court's ruling on the prior restraint objection freed injunctions regulating picketing from a presumption of invalidity. Its ruling on the applicability of the rule against content regulation had a similar effect: No presumption of invalidity should attach simply by virtue of the fact that an injunction is addressed to some particular group of protestors (and not others). In reaching this conclusion the basic sympathies of the majority were manifest: The Justices saw the danger and believed that the injunction could play a useful role in setting the bounds of the confrontation. Yet, also to its credit, the Court was careful not to create a presumption of validity in favor of the injunction. The Court was prepared to review the injunction case-by-case, indeed provision-by-provision, to see whether First Amendment values were fully respected. Injunctions regulating picketing in front of abortion clinics were to be judged on a retail, rather than a wholesale, basis.

III.

Doctrinal disputes on the First Amendment often revolve around the level of scrutiny-strict? intermediate? ordinary? - that is to be applied to the challenged regulation. Madsen provided new material for the treatise writers by creating a standard putatively in-between "intermediate scrutiny" and "strict scrutiny" for judging an injunction regulating picketing. According to the Court, the particular restraint must serve a government interest that is "significant," and in pursuit of that end, the regulation must "burden no more speech than necessary." 18 In a 1997 sequel, Schenck v. Pro-Choice Network of Western New York, a majority of the Court reaffirmed this test. ${ }^{19}$ The Court's opinion was once again written by the Chief Justice. There was another high-pitched dissent by Justice Scalia.

In both Madsen and Schenck, the Court used the new in-between test to justify buffer zones between the picketers and the entrance or driveways of the clinic-in Madsen the buffer zone was 36 feet; in Schenck it was 15 feet. (In Schenck, the injunction allowed two protestors, known in the trade as "sidewalk counselors," to enter the buffer zone to talk to the person entering the clinic, on the condition that they withdraw once the would-be patient indicated that she wished the conversation

17. Norris-La Guardia Act, ch. 90, 47 Stat. 70 (1932) (codified as amended at 29 U.S.C. $\$ \S 101-15$ (1982)). For more on the use of the injunction in the labor context, see FELIX FRANKFURTER \& NATHAN GREENE, THE LABOR INJUNCTION (2d ed. 1963).

18. Madsen, 512 U.S. at 765.

19. 117 S. Ct. 855 (1997). 
to end.) In each case, the Court struck down a number of other provisions of the injunction on the theory that they were broader than necessary to serve the relevant state interest-in Schenck the invalidated provision created a floating buffer zone that traveled with persons entering the clinic; in Madsen the invalidated provisions created a 300-foot zone around the clinic in which protestors could not approach would-be patients who did not consent to talk, as well as establishing similar zones around certain private residences and barring the use of images observable by patients in the clinic. ${ }^{20}$ Yet the principal thrust of both these decisions was to legitimate the creation of a physical space-a buffer zone of modest proportions - between the picketers and the entrance or driveways of the clinic.

The creation of such a zone seems wholly consistent with the First Amendment and effectuates a just accommodation of the conflicting interests. Scalia felt that by pushing the picketers back from the entrance of the clinic the state is siding with the pro-choice forces and thus breaching its duty to be neutral between contending viewpoints. But this is not so. What neutrality requires in this context is that the restraint be justified on grounds that are independent of the merits of the underlying dispute. What justified the buffer zones created in Madsen and Schenck was not a desire to disfavor the protestors or a hostility to their views, but rather another set of interests altogether-in the Court's mind, public safety and order, promoting the free flow of traffic, protecting property rights, and the freedom of women to seek pregnancyrelated services. ${ }^{21}$

In the town meeting, where speech is enlightenment and the state is the parliamentarian, the intervention of the state could be judged in terms of effects. Even if the ruling of the parliamentarian rests on neutral grounds, it may have the effect of disadvantaging one side and for that reason interfere with self-governance. Imagine, for example, a ruling that required all speakers to use microphones even though the state does not provide them. The decision not to provide microphones might be based on a resource constraint, and the requirement of using a microphone might be based on consideration of audibility. Still, the unequal impact, and the threat to First Amendment, would be manifest. The poor would be less able to speak, and public debate would be skewed.

In the context of picketing, however, we cannot hope for neutral effects. The space for that kind of neutrality does not exist. Two parties are symbolically locked in combat; any intervention by the state will necessarily alter the terms of the encounter and thus affect the balance of power. In terms of effects, state intervention can never be neutral. Nor would standing on the sidelines, doing nothing, be neutral in terms of effects, for that simply affirms the status quo and its distribution of power. All that one can hope for in picketing is neutrality of grounds, knowing full

20. The Madsen Court did, however, uphold a restriction on the amount of noise the picketers could make. See Madsen, 512 U.S. at 773.

21. See Madsen, 512 U.S. at 768; see also Schenck, 117 S. Ct. at 866. 
well that even if that can be achieved, the order will have non-neutral consequences - the pro-lifers may be pushed back and in that sense disfavored.

What neutrality of grounds seeks to ensure is that the state cannot silence or disadvantage a party to a dispute simply because it disagrees with that party's position--the state cannot decree that one side is right and the other wrong. At the very foundation of the First Amendment, as Justice Brennan pointed out in the flagburning case, ${ }^{22}$ lies the principle that prohibits state officials from suppressing speech simply because they happen to disagree with it. It is that principle which requires the Court, at a minimum, to look at the reason for the regulation of speech.

In Schenck, the Court went beyond Madsen to make clear that the reason requirement was to be objectively understood: What matters is not what actually moved the judge, but rather what could be said on behalf of the injunction. This issue arose in the context of assessing the provision of the injunction allowing two socalled "sidewalk counselors" to enter the buffer zone to talk to the would-be patients. As a restriction on the grant of access, the District Court provided would-be patients with a cease and desist power-the right to stop conversations whenever they desired. This power, the judge said, is needed to protect their right to be let alone.

Addressing the cease-and-desist power, the Supreme Court commented, "We doubt that the District Court's reason for including that provision-to protect the right of the people approaching and entering the facilities 'to be left alone'accurately reflects our First Amendment jurisprudence ...."23 The Court went on to conclude, however, that the cease-and-desist power could be justified as a means of preventing "harassment" and "intimidation." Although the District Judge had not used fear of harassment or intimidation as the predicate for the cease-and-desist power, the Supreme Court noted that he had found that sidewalk counselors had been arrested for harassing and intimidating would-be patients and that they persisted in that objectionable conduct after their arrests. For the Supreme Court what was crucial was the possible, not the actual, ground of decision. If grounds for the intervention existed that were neutral between the contending forces, then it could not be said, at least on one level, that state officials were disfavoring one side because it disagreed with its position or was offended by it. The judge's motivation was wrong; but that error had no practical effect, for good grounds existed for his action.

Neutrality of grounds is not, however, the entire measure of the state's duty. The First Amendment also entitles protestors to a reasonable opportunity to publicly encounter the alleged wrongdoer, for without such a public encounter, there can be no confrontation or witnessing in the classical sense, and the democratic values served by such protest activity will remain unfulfilled. In the context of a town meeting, the requisite social interaction is assumed by the metaphor itself. All the

22. Texas v. Johnson, 491 U.S. 397, 414 (1989) ("If there is a bedrock principle underlying the First Amendment, it is that the government may not prohibit the expression of an idea simply because society finds the idea itself offensive or disagreeable.")

23. Schenck, 117 S. Ct. at 870 . 
people are sitting in one room, debating one another. But when we turn to picketing, the forum for the encounter cannot be assumed; it is created by the state in the act of defining the bounds of the protest.

In both the Madsen and Schenck cases, the Court seems fully sensitive to the need to give the protestors a reasonable opportunity to encounter the alleged wrongdoers. As already noted, in Madsen the Court struck down a provision requiring a 300-foot zone around the clinic in which sidewalk counselors could not approach would-be patients who did not consent to talk. Such a large buffer zone-the size of a football field-would seem to destroy the possibility of a public encounter between the protestor and the alleged wrongdoer. This cannot be said either of the 36-foot buffer zone of Madsen or the 15-foot one in Schenck. Both permit the picketers and the persons entering the clinic to be in clear view of one another and in fact to be physically proximate. Of course, the picketers wanted to be even closer, indeed to block access, but these buffer zones accommodated the needs of those wanting to use the clinic and at the same time preserved the capacity of the picketers to confront or witness those who chose to enter.

The Court seemed, however, less sensitive to First Amendment interests and the need to preserve the opportunity of confrontation when it addressed the issue of residential picketing. Admittedly, the Madsen Court invalidated an injunctive provision that created a no-picketing zone around the residences of the staff of the abortion clinic. That zone was 300 -feet, and the Court struck down this provision as excessive. But the ruling of greater import-both practically and theoretically-on this issue occurred a number of years earlier in Frisby v. Schultz. ${ }^{24}$ In that case the Court effectively eliminated the home as a site of confrontation.

At issue in Frisby was a regulation prohibiting picketing in residential areas. This regulation took the form of a municipal ordinance rather than an injunction. Accordingly, the prior restraint doctrine was not applicable. Nor was the rule against content regulation. As a purely historical matter, the ordinance was passed in response to protest activity aimed at a doctor who performed abortions. But the ban enacted applied to all picketing in residential areas and thus could not be attacked on grounds of the rule against content regulation. Since neither the prior restraint doctrine nor the rule against content regulation were available, the would-be picketers turned to yet another First Amendment doctrine, namely, overbreadth.

The overbreadth doctrine allows the Court to invalidate a law regulating speech whenever the law could be applied to an activity that is constitutionally protected. ${ }^{25}$

24. 487 U.S. 474 (1988).

25. For a more extensive treatment of the overbreadth doctrine, see Owen M. Fiss, Dombrowski, 86 YALE L.J. 1103 (1977). See also Note, The First Amendment Overbreadth Doctrine, 83 HARV. L. REV. 844 (1970). Overbroad statutes are similar to vague statutes in that both restrict (or may be read to restrict) constitutionally protected activities. The now classic Note by Professor Anthony Amsterdam is an excellent starting place to explore the issue of vagueness and its relationship to overbreadth. See Anthony Amsterdam, Note, The Void-for-Vagueness Doctrine in the Supreme Court, 109 U. PA. L. REV. 67 (1960). 


\section{7/The Unruly Character of Politics}

Some of the applications of the law may cover unprotected activity, and some protected activity, but the very possibility of applying the law to protected activity renders the law invalid on its face. The law sweeps too widely, as it has been put. To give substance to that claim in Frisby, the Court was asked to imagine a single, solitary picketer, standing quietly on public property in front of the doctor's house, accusing him of murder. In response, the Court acknowledged that the challenged ordinance could apply to such a situation, but then went on to reject the overbreadth claim on the ground that such picketing is not protected by the First Amendment.

In reaching that conclusion, Justice O'Connor, writing for the Court, characterized the interest the state was protecting as the right to privacy. Seen in those terms, there was a conflict between two prized rights-privacy and speech-and the municipality was allowed to strike a balance in favor of privacy. The problem, however, is that the right of privacy, as ordinarily understood, was not threatened. Because the picketer imagined to test the overbreadth claim stood alone and silently on public property, there was, by hypothesis, no intrusion into the home or property of the doctor-no physical entry, no trespass, no electronic projection of the message, no shouting.

Privacy is a term with many meanings, especially in the law, and O'Connor may have used it to refer to a "right to be left alone."26 On a number of occasions, most recently in Schenck, the Court expressed considerable doubt as to whether there was any generalized "right to be left alone" on a public street or sidewalk, at least not a right that could be used to silence protest, but when it came to the home the Court seemed to be of a different mind. The Frisby Court ruled that in the home there seems indeed to be "a right to be left alone," which in practical terms makes it permissible for the state to ban all picketing in front of a home, even if it is peaceful, quiet, on public property, and consisting of a single person. To reach such a conclusion, O'Connor must have reasoned that there is a need for zones of disengagement where people do not have to confront the moral implications of their actions. Doctors can be confronted in the business sections of the city, where they work, at the office or clinic, but not when they are at home. There they are entitled to be free of the worries of the day.

In Frisby, Justice Brennan, joined by Justices Marshall and Stevens, dissented. Brennan acknowledged the capacity of the state to regulate residential picketing-it must be on public property, be peaceful, and not intrude into the house of the doctor. Yet he objected to the capacity of the state to remove all picketing from a residential area, including the solitary picketer imagined for the purposes of the overbreadth claim. Such a restriction legitimates a certain moral escapism and thus a lessening-not an abandonment, but only a lessening-of the commitment to confrontational politics that seemed to him so essential to democracy.

26. For the original articulation of this now controversial right, see Samuel D. Warren \&\& Louis D. Brandeis, The Right to Privacy, 4 HARV. L. REV. 193 (1890). 
In the quiet suburban neighborhoods of contemporary America few people walk the streets. Having a group of people or even one person lurking mysteriously outside your home is an oddity, and, of course, a source of anxiety. This is the anxiety of physical presence-a fear that the stranger may try to enter your home or physically attack you on the way out. No one should have to suffer that kind of anxiety and the state should take appropriate precautions against the conduct that gives rise to it. The anxiety produced by the abortion picketer is of another character altogether-it is a moral anxiety. The doctor is being accused of committing of a heinous crime, specifically, murder, and the presence of the solitary picketer in front of the doctor's house is a constant reminder of that accusation. By definition, an act of confrontation must indicate the grounds of opposition.

The abortion picketer may create both types of anxiety-a physical as well as a moral anxiety. The doctor may fear, in the spirit of the recent T. Coraghessan Boyle story, ${ }^{27}$ that the picketer may put down his signs and rush his house, or turn angry and assault him and his family as they enter or leave their home. The state can surely respond to this danger, but not, if the overbreadth doctrine is to have any meaning, by banning every one from standing, walking, or patrolling in front of the residence. The state cannot ban strangers from standing outside the doctor's house. What it can do is post police officers in front of the house, escalate the stakes for physical assaults or physical entry, regulate the number of persons picketing the house, and keep all picketers at a distance from the doors and driveways-all in keeping with the spirit of Madsen and Schenck. These measures may provide the doctor with physical protection but not a respite from politics.

Moral anxiety, of course, has its costs-indeed that is the very point of the exercise. Faced with the prospect of having even a single, solitary figure in front of his house every hour of the day, accusing him of murder, the doctor might well decide to get out of the business of performing abortions. As a result, women who live in that community might not be able to exercise the choice extended to them by the Constitution. Justice Brennan was not unmindful of this risk and surely would be sad if it materialized. Crucial as he was to the formation of the majority in Roe $v$. Wade, he must have hoped that the imagined confrontation would not result in the lessening of women's choice. Yet his inclination was to rely on the resiliency of the doctor rather than a command of the state to fulfill his hope. For him, democracy grants rights but also imposes duties-perhaps a duty to listen-and denies the possibility of escaping the moral implications of one's actions merely by driving home. ${ }^{28}$

27. T. Coraghessan Boyle, Killing Babies, THE NEW YORKER, Dec. 2, 1996, at 86.

28. The notion of a duty to engage in political dialogue is one of the foundational principles of democratic self-governance, with deep roots in First Amendment jurisprudence. See, e.g., Whitney v. California, 274 U.S. 357, 375 (1927) (Brandeis, J., concurring) ("Those who won our independence believed that the greatest menace to freedom is an inert people; that public discussion is a political duty; and that this should be a fundamental principle of the American government.") 
In their handling of clinic picketing, the Justices appear to have grasped the imperfection of the electoral process and the essential role of citizen protest in a democracy. The buffer zones which the Court legitimated worked a sensible accommodation of the competing interests of the protestors and those who are entitled to use the clinics. In fact, Madsen and Schenck, both written by Chief Justice Rehnquist, might well be taken as a credit to his stewardship. But the Justices stumbled when they turned in Frisby from the clinics to residential picketing. Moved by the special attachment they obviously feel toward their homes, a sentiment probably shared by most Americans, they compromised the democratic commitments that guided them in Madsen and Schenck.

The home is indeed different. It is the locus of our most intimate relationships and, on the best days, provides some peace from the rough and tumble of the world. These differences can be safely acknowledged, however, without turning the home into a refuge of moral escapism. Quite the contrary. Home should be the very place where we weigh most seriously the implications of our actions. We must use the love and tranquility that it provides to search our consciences and, through that silent dialogue known as thought, respond to those who bear witness to all we have done. 